\title{
Abrupt Termination of Employee Contracts In a Democratic State: The Case of Botswana
}

\author{
Baakile Motshegwa (Corresponding Author) \\ University of Botswana \\ Department of political and Administrative Studies \\ Private Bag UB00705, Gaborone, Botswana \\ Tel: +2673552742Ｅmail: Motshegwa@mopipi.ub.bw
}

Fax: +2673170706

Keratilwe Bodilenyane

Ministry of Agriculture

Department of Animal Production

P. O. Box 342, Mochudi, Botswana

Tel: +2675777288 Email: ratiiker@yahoo.com

Fax: +2675777078

Received:November 01, 2012 Accepted:December 11, 2012 DOI:10.5296/jpag.v2i4.2611

\begin{abstract}
Botswana has in the past received accolades of being the most peaceful country in Southern Africa. Any disturbance of this peace is either shunned or seen as a departure from the norm. The advent of trade unions in Botswana has always been looked at with suspicion and they have been seen as militant, which is contrary to the peaceful existence the country has enjoyed regardless of the fact that it is surrounded by countries that have been to war at some point in their history. Therefore, the state has made it a point that any sign of unrest is severely dealt with by the government. Some employees were dismissed un-procedurally as disciplinary procedures were not followed and the court ruled in the employee's favour in 2012. The majority of those dismissed were from the essential services sections of government even though at the beginning some were released through the strike rules agreement between government and unions. Laid down disciplinary rules and procedures of having a hearing were not followed.
\end{abstract}

Keywords: Industrial relations, Botswana, democracy, unions, strike 
1. Introduction

The 2011 industrial relations developments in Botswana's public service have been horrific as the country had never experienced a strike of that magnitude. The industrial relations in Botswana have turned to be like that of market individualism because it is characterized by weak labour that is subordinate to the employer through the indirect control of the politicians. According to van Warden (1995) diversity in national industrial relations systems is significantly related to the differences in degree, method, and content of government intervention not only into the industrial relations system itself but also the wider economic and social framework. Most people would agree that the Botswana government has become the primary force in determining the nature of industrial relations. The government's relationship with the labour movements was tested in 2011 when an eight week civil servants strike resulted in unfair dismissals of some of the civil servants with disturbing and unending courts cases. Even though there is legislation to protect employees, the functions of the unions have become ineffective.

The unions have witnessed marginalization in industrial relations exacerbated by a more active and direct state intervention in establishing terms and conditions of employment. It can be argued that the marginalization of the unions in Botswana boils back to the system of government. Botswana has a presidential system of government. In presidential system the President is vested with enormous powers that make it possible for the government to be the primary actor in industrial relations. This arrangement place the unions in a subordinate position because government is neither a neutral representative of the public or social interest' nor 'a captive of class forces, economic forces or the capitalist mode of production- but rather has some degree of relative autonomy that the unions do not have (Salmon, 2000). Hence the unions will always bargain from a disadvantaged position.

\section{Background Information}

This conceptual paper is motivated by the recent developments in Botswana that symbolizes the form of 'state corporatism', where the unions are suppressed, and or subordinated. Such approach has, in the past, been associated with the former Communist countries of Eastern Europe and, at the opposite end of the political spectrum, Spain under the Franco regime (Salamon, 2000). Bean (1994) pointed out that, the subordination of the union movement to the needs of economic development has also been central to part of government strategy in some newly industrialized countries such as Malaysia, Singapore and Korea, to the extent that the primary actor in the industrial relations scene is the government itself (Bean, 1994).

Without any shadow of doubt, one would expect industrial actions to be minimal in a country that uphold democracy such as Botswana. Democracy is the extent to which governments are responsive to the needs of the people and properly accountable to their actions (Danevad, 1995). Hence the greater the opportunities for expressing, organizing and representing political preferences, the greater the number and variety of preferences and interest that are likely to be represented under a democratic setup (Diamond, 1991). It has been argued that Botswana has been able to enjoy uninterrupted peace and progress in virtually all areas of human endeavor (Nsereko, 2004). But the industrial action of 2011 by the civil servants 
disagrees with this assertion. The strike culminated in termination of employment contract of some of the essential service employees and numerous court cases. Therefore, the paper seeks to establish whether the process leading to dismissal of the concerned employees was substantively and procedurally fair.

In addition, democracy has to do with how government, interest group leaders exercise their power-not just their commitment to democracy in principle, but their ability to bargain with one another, form coalitions, mobilize public support, and respond to public pressures and preferences (Diamond, 1999). Even in presidential systems where elites may be preeminent, mechanisms must exist for making it responsive to the passions, preferences and interests of the civil servants. Hence unions are one of the instruments that are essential to make the government responsive to the rights, preferences and interests of the civil servants. During the wage negotiations between the government and the unions, the government re-tabled a conditional offer of a $5 \%$ increase. This was conditional because such adjustment was to be made only if the economy continues to improve, allowing it to meet its deficit reduction targets. On the other hand the unions indicated that they were prepared to lower their salary adjustment from $16 \%$ to $13.8 \%$. Upon failing to reach a consensus the civil servants embarked on industrial action. In terms of the Trade Dispute Act 2003, Cap 28: 02, (Laws of Botswana), every party to a dispute of interest has the right to strike or lockout if all the requisites of a lawful strike prescribed by the Act have been met. Even though every employee has the right to strike, it was argued that the industrial action by some of the employees was unlawful as they are classified as essential service employees. Following this, the employer took the striking workers to court on the basis that they are not allowed to strike. The Industrial Court then issued an interim Order on the 26 of April 2011 that the strike undertaken by all civil servants employed in all essential services defined by Trade Dispute Act was illegal, hence the concerned employees were ordered to return to work. Feeling aggrieved the unions appealed. Disappointingly, following the Order of the Industrial Court for the concerned employees to return to work, on the $16^{\text {th }}$ May 2011 the employer dismissed employees who she said refused to return to work and continued to participate in the unlawful and unprotected strike. If things are done procedurally and lawfully, it should be understood that the Order of 26 April 2011 for the concerned employees to return to work was nullified by a notice of appeal that was filled on the $6^{\text {th }}$ of May 2011.

\section{Disciplinary Process and Dismissal}

The purpose of this section is to provide a comprehensive discussion of the legal jargon and complexity of the law of dismissal as it transpired during the 2011 civil servants strike. Section 27 of the Employment Act points out conditions upon which termination of employment can be effected. It thus state that employee guilty of serious misconduct shall be summarily dismissed from the service.

Generally misconduct relates to deliberate and willful action or behavior by an employee that leads to breach or contravention of a rule, obligation or standard in the workplace (Lotter \& Mosime, 1983 \& Nel et al, 2008). Misconduct is also a deliberate and willful violation of the employer's rules as well as unreasonable or unacceptable conduct such as abusive behavior 
and or being under the influence of alcohol (Dessler, 2008 \& Cole, 2002). Because of misconduct employees can be dismissed from work with or without notice. This action may be regarded as fair only if it is related to the conduct or the capacity of the employee, related to the operational requirements, and effected in terms of a fair procedure (Bendix, 2001). The maintenance of discipline in the workplace is essential, and it is the employer's prerogative, the employer may have no option but to terminate the contract of employment, however, it should be guided by laid down disciplinary rules and procedures. Several authors and guidelines are in agreement that the substantive and procedural considerations have to be taken into account in the event the final verdict amounts to dismissal for misconduct.

According to Lotter and Mosime (1993) substantive considerations are guided by (i) the existence of a rule, obligation or standard, (ii) the legitimacy of the rule, (iii) knowledge of the rule, (iv) breach of the rule and (v) the appropriateness of the sanctions. Nel et al. (2008) affirm this by arguing that any person, organ or body that determine whether the dismissal for misconduct is fair or unfair, should consider whether the employee contravened a rule or standard regulating conduct in or of relevance to the workplace. If the rule or standard was contravened, the person, organ or body should therefore, consider whether or not; the rule was valid or reasonable rule or standard the employee was aware, or could reasonably be expected to have been aware of the rule or standard, the rule or standard has been consistently applied by the employer, and the dismissal was an appropriate sanction for the contravention of the rule or standard. In view of the foregoing, a dismissal is regarded substantively unfair if the employee was unaware of the rule or standard broken by him or her, there is no clear reason for dismissal, there was insufficient proof of misconduct, the sanction is too severe for the offence which was committed, the expectation of the employer were unreasonable or unlawful and, the dismissal constitutes the victimization of the employee. It has been clear that, the employees who failed to report to work during the 2011 civil service strike were dismissed for the misconduct implicit in their continued participation in the strike, and none of them was offered a hearing prior to the imposition of the sanction. The employees were victimized just because the employer failed to discharge her duty to give the employees or their representatives a hearing before deciding to terminate their service. In addition the employees who have been dismissed were not aware of the rule being broken because the Order to return to work on 26 of April 2011was nullified by a notice of appeal that was filled on the $6^{\text {th }}$ of May, 2011 (Botswana Land Board and Local Authorities Workers Union and Another v. Attorney-General, 2012). Hence the dismissal was too severe for the offence that was committed by the employees. According to Mr M.S.M Brassey SC, the counsel for the civil servants, the decision to terminate the contracts of public officers constituted an exercise of public power and was susceptible to judicial review in accordance with well recognized principles of administrative law.

The employer should understand that the purpose of the disciplinary procedure is to provide an acceptable mechanism within which management may exercise its control over employees when their performance or behavior does not reach the required standards (Salmon, 2000). This also seeks to ensure observance of the required standards, and that a fair and systematic process is followed in case an employee allegedly fails to oblige. Even though other scholars 
argue that disciplinary action not only involves subjective concepts of 'fair' and 'reasonable', 'right' or 'wrong', but also concerns the power, authority and status of management (Salmon 2000: 565). The management should at all cost exercise moral and ethical elements at all stages. In the event of a breach of discipline, management has the right and responsibility to take appropriate action. The objective of disciplinary action, is to bring about change in undesirable behavior, and should not be used in a vindictive manner, (Briscoe, 2000). However it was argued that there could never be individual disciplinary hearings in circumstances where the affected employees have ignored all pleas by government to return to work. The employer in the case at hand argued that, by their own conduct employees had rendered it impossible to hold disciplinary hearings. Judging by the progression of the strike the industrial action was peaceful and no violence existed. It is argued that no confirmatory affidavit of the person who witnessed the violence was filed in high the court. Hence the employer failed to ensure that employees are treated fairly and not disciplined or dismissed at the whim of the government. The employees should have been accorded the opportunity of a fair hearing before dismissal.

If at all costs, the employer sees it fit not to accord the employees a hearing before dismissal, the employer must, at the earliest opportunity, make reasonable attempts to contact a trade union official to discuss the course of action it intends to adopt. On the other hand, procedural fairness requires that an inquiry into the matter or alleged misconduct has to be lodged prior to the decision taken to dismiss. In other words, the employer should conduct an investigation to determine whether there are grounds for dismissal. Following this, the employer should warn or notify the employee of the allegations. However, this did not happen prior to dismissing the concerned employees. One may also wonder about the motives behind the swift action of the employer in dismissing the employees. In addition if dismissals are contemplated, the employer should issue an ultimatum in clear and unambiguous terms that should state what is required of the employees and what sanction will be imposed if they do not comply with the ultimatum. Even though Ms Festina Bakwena, the Director of Public Service Management argued that they gave several ultimatums to essential service employees to obey various Court Orders to return work, the channel they took was inappropriate. The ultimatums were just announced on television and no ultimatum was directed to the unions who were the representatives of civil servants. Hence the unions were sabotaged and not accorded any respect.

The employer should have considered a number of relevant factors that may have resulted in less punishment rather than dismissal. In essence, dismissal should be considered as a last resort, hence need to ensure that all aspects of procedure have been exhausted and ultimate actions are for a valid reason. However, the government made no effort to bring the Court Orders to the attention of each individual employee. Mr Motsamai the Secretary General of Botswana Federation of Public Sector Unions, argued that before the applicant's member involved in the provision of essential services could reflect on the Order of the $10^{\text {th }}$ of May, 2011, and the advice of the Unions that they were required to return to work, the Government announced on the $16^{\text {th }}$ of May, 2011, that all persons providing essential services who had failed to show up for work despite Orders granted on the $26^{\text {th }}$ of April, 2011, $6^{\text {th }}$ May and $10^{\text {th }}$ 
May, 2011, were dismissed ( Botswana Landboard and Local Authorities Workers Union and Another v. Attorney-General, 2012). Procedurally the employees should have been allowed sufficient time to reflect on the ultimatum and respond to it, either by complying with it or rejecting it. The unions argued that there was no sufficient time for the applicants to communicate the Order of the $10^{\text {th }}$ May 2011, to their members having regard to a number of factors such as the vastness of the country. To some extent the media which the government used to convey the notices to essential service employees to return to work immediately could have not have enough coverage. It cannot also be ascertained how long the employees knew that the strike had been declared illegal, hence they continued to participate in the strike.

Important to note is that in times of troubles or whatever circumstance that warrants intervention, employers or most appropriately the government should exercise their ability to bargain with one another amicably and respond to public pressures and preference. In concurrence Molomo (1998) argued that democracy in its practice requires the participation of the people. As such under a democratic setup one would expect direct engagement of the government, the employer and the unions, which is necessary to ensure mutual respect, listening and appreciation of advises from all the concerned stakeholders. Hence the trends during the strike have been characterized by individual action, reflective of individual genius which calls for special explanation in a democracy.

In addition, a democratic state like Botswana should effectively address society's most pressing problems and, perhaps more important, provide the liberty, accountability and responsiveness that citizens uniquely expect from democracy and the order that they expect from any government (Diamond, 1999). Despite the need for effectively addressing the societies pressing needs through fair bargaining, the employer decided to withdraw negotiations during the historic civil service strike of 2011 and it seems it was only the employer who had the plan for the wage dispute. The situation was further made complex by the fact that it is only the President who has the monopoly to summon parliament at times of emergencies or when need arises. Therefore, all the efforts to ask for a special parliamentary sitting to resolve the employee's grievances were dismissed because the parliament does not have the power to call a special Parliamentary session. Member of Parliament for South East, Mmoloki Raletobana lamented that the Constitution is centered on one person and if he or she does not call a special Parliamentary session, they are all helpless (Botswana Democratic Party MPs Speak Out, 2011). All this demonstrate that even if the unions can fight for the rights of employees it will be just a losing battle with an executive presidency.

\section{The unlawful court cases}

In a democratic state, freedom and pluralism can be secured only through a 'rule of law' in which legal rules are applied fairly, consistently, and predictably across equivalent cases, irrespective of the class, status, or power of those subject to the rules, and the state and state agents are themselves subject to the law (Diamond, 1999). But in a situation where power is vested in one person or the Office of the President to set up or decide the structures that will protect liberty, power is likely to be abused, hence decay of democracy. Liberty should be secured through constitutional, limited government and a rule of law, hence need for a strong 
independent judicial system.

Although the Judiciary is independent of the government, this may not always be the case. Salamon (2012) argued that this autonomy arises from the judiciary having a 'mediatory role' in social relations. Several other scholars cite the apparent hostility of the Judiciary towards the interests of employees and trade unions as evidence of its autonomy being supportive of the dominant ideology within the society. Botswana is not an exception in this trend. This is so because while the Industrial Court is at par with the High Court and the Court of Appeal, its judges are appointed directly by the President, while those of the Court of Appeal and High Court are appointed in accordance with the advice of the Judicial Service Commission. Hence it is likely that when the judges adjudicate on cases they may take the side of the government, because one cannot 'bite the hand that feeds them'.

Another essential component of democracy is that individual liberties are effectively protected by an independent, nondiscriminatory judiciary, whose decisions are enforced and respected by all centers of power (Diamond, 1999). In a constitutional state the courts should be able to enforce restrictions on popularly elected governments when they violate the laws or constitutional rules. Nonetheless the society has witnessed lack of restraint by Botswana's judicial system during the civil servant strike. Mr Brassey, the counsel for the civil servants, argued that even if the participation of the essential employees in the strike constituted misconduct, the provisions should have been followed. It is allegedly argued that the leaders violated the law when they enforced the industrial Court Order, arrogating its powers. According to the Botswana National Front leader, Duma Boko, under normal circumstances the whole process should have taken place in the court and is not something to be cited by government (Kereng, 2011).

It is quite disturbing to realize that in a democratic state like Botswana the government can just act outside its mandate despite the fact that judges should be the final arbiters in disputes. One would expect the judicial system to have exercised their restraint to prevent the abuse of power by the state. However due to judicial impartiality the striking workers were not given an opportunity by the courts to defend themselves as to why they did not obey the Court Order. Indeed this was observed by Salamon (2000) who argued that a court that intervenes in an industrial conflict cannot be 'neutral', it will take one side or the other, and generally in doing so will add the weight of 'legal right' to management side. It is important to understand that quality of democracy is demonstrated by an autonomous judiciary, as well as institutionalized means (often in separate, autonomous agency) to monitor, investigate, and punish government corruption at all levels (Sklar, 1987). The judgmental process should be in such a way that the Judiciary decides between the rights of contestants in any particular case rather than mediate a compromise.

\section{Recommendations}

1. Trade unions should be involved in government policy formulation and have the status of quasi-governmental institutions. This means that there should be frequent consultations between the unions and the government, not necessarily that the unions should be part of government decision making. The government should include all 
stakeholders in economic and social planning-a social contract.

2. There is need for an impartial judicial system. Therefore the Industrial Court judges should be appointed with the advice of Judicial Service Commission. This is important so that the nature of the judges and the judgmental process should at all cost be able to enforce restriction on every individual and the popularly elected government when they violate the laws.

3. Even though the Act provides that nothing shall prevent any employer or employee from being proceeded against according to law for any offence punishable under any other law (Sec 152) it is felt that the necessary steps for disciplinary hearing before dismissal should be followed as enshrined in the Act, as it is the practice in other countries. One example of such countries is South Africa, which has recognized and assimilated substantive and procedural issues that have to be proved or disapproved in cases of dismissal for misconduct in its labour laws in line with the International Labour Organization (ILO) Conventions and Recommendations.

4. It is evident that there is lack of familiarization by the employer, the government and the employees (unions) on the labour laws as it has been identified by weak and haphazard decision making in the whole 2011 strike negotiation process. Therefore, it is suggested that all the stakeholders should be trained on specific requirements regarding misconduct, disciplinary actions and dismissals.

\section{Research implications}

A qualitative methodology was used for this study to find out in depth about the relationships between government and employees who went on strike which eventually led to their dismissal. Future research should focus on the quantitative methodology that will be able to cover a wider area of study that will lead to the finding that will be more generalizable. State or the role of the executive and union relationship also needs to be studied in-depth so that all necessary procedures are followed before mass dismissal are considered. Research could also focus on the skill of both parties - union and government officers on how to handle industrial relations matters following all the necessary statutes like the Employment Act and the Trade and Disputes Act.

\section{Conclusion}

Labour laws should be respected because they play an important role in promoting decent work and responding to current social and economic challenges. It is concrete expression of fundamental principles and rights at work. It establishes a regulatory framework that guarantees transparent and consistent processes and expeditions and reliable decision making on issues relating to employment relations. It provides a normative basis on which employers and workers, and their representatives can interact with one another and with governments and it therefore serves as an important instrument in promoting industrial and workplace democracy (Kirsten et al., 2008). In addition it should be understood that in a presidential system like that of Botswana, unions are one of the instruments that are essential to 'keep the government on its toes' regarding the interest and rights of the civil servants. Hence need for 
the unions to be accorded respect and recognition not just to be used for ceremonial purposes.

It is important to note that government is not just an employer, but a custodian for the livelihoods and welfare of each and every citizen. It destroys government of Botswana's reputation, to find that the unfairly dismissed workers remain in the streets, unemployed and without a wage. We ought to have a government that is unique, set apart or different from the private sector in dealing with industrial issues, she should lead by example. Lack of knowledge by management and employees on the type of offences that warrants dismissal can breed confusion and lack of transparency towards conflict resolution. In conclusion it seems the employer is not doing well in managing industrial relations. In keeping with global trends, there is need to make reference to the ILO standards of management. Hence all that happened during the 2011 civil service strike should be a lesson for the future.

\section{References}

(2011). BMD MPs speak out. The Voice, May 20, p4.

Bean, R. (1994). Comparative Industrial Relations ( $2^{\text {nd }}$ edition). New York: Routledge.

Bendix, S. (2001). Industrial Relations in South Africa, ( $4^{\text {th }}$ edition). Lansdowne: Juta \& Co. Ltd.

Botswana Landboard and Local Authorities Workers Union and Another v. Attorney-General. (2012). Botswana Law Report. 1-70.

Briscoe A. (2000). Holding a Discliplinary Hearing. Gaborone: Morula Press.

Cole, G. A. (2002). Personnel and Human Resource Management ( $5^{\text {th }}$ edition). London: Book Power.

Dessler, G. (2008). Human Resource Management (11 ${ }^{\text {th }}$ edition). New Jersey: Pearson Education International.

Directorate of Public service Management. (2011). Strike rules agreement between Directorate of Public service Management representing government as the employer and five of the recognised unions affiliated to BOFEPUSU (BOPEU, BLLAHWU, BTU, BOSETU AND NALCGPWU). Gaborone: Botswana.

Hollinshead, G. \& Leat, M. (1995). Human Resource Management: an International and Comparative Perspective. London: Pitman.

Kereng, E. (2011). Government violated law by enforcing industrial court order-Boko. Mmegi, 27 May, p2.

Kirsten, M. (2008). Labour Relations Management. Pretoria: University of South Africa.

Lotter, C. \& Mosime, K. (1993). Arbitration at Work. Wetton: Juta \& Co. Ltd.

Morewagae, I. (2012). Government has not engaged BOFEPUSU over complaints registered with ILO. Mmegi, 30 May, p3. 


\section{Macrothink}

Journal of Public Administration and Governance ISSN 2161-7104 2012, Vol. 2, No. 4

Nel, P. S. (2008). South African Employment Relations (6 ${ }^{\text {th }}$ edition). Pretoria: Van Schaik Publisher.

Rapitsenyane, P. (2012). Decision unlawful-Advocate Brassey. Dailynews, 11 May p8.

Republic of Botswana. (2002). Employment Act. Botswana: Government Printer.

Salmon, M. (2000). Industrial Relations: Theory and Practise (4 ${ }^{\text {th }}$ edition). England: Pearson Education Limited.

van Warden, F. (1995). 'Government intervention in industrial realtions', in J. van Ruysseveldt, R. Huiskamp and J. van Hoof (eds), Comparative Industrial and Employment Relations. London: Sage. 